\title{
PERANAN KEPEMIMPINAN KEPALA MADRASAH SEBAGAI MANAJER DALAM MENINGKATKAN MUTU PENDIDIKAN
}

\author{
Hafizin \\ Sekolah Tinggi Agama Islam Al Hidayah (STAIA) Bogor \\ email: hafizin@staiabogor.ac.id
}

\begin{abstract}
This study aims to: Analyzing the form of madrasa head strategy as a manager in improving madrasa quality in MI Wali Songo Asy-Syirbaany, South Tangerang. The data were collected through observation and interviews and then analyzed using the Moleong et al approach namely checking the correctness of the data from several sources that were considered to have good knowledge regarding the focus of the research being studied. The results obtained from this study, namely: Madrasa head strategy as a manager in improving madrasa quality, which includes three things, namely input, process, and output. Input in the sense of a strict selection for new students and teachers who want to teach at MI Wali Songo Asyirbaany. These three things are interrelated with one another, without good input and learning processes, the output produced by an educational institution will also not be maximal.
\end{abstract}

Keywords: head of madraah, manager, quality of education

\begin{abstract}
ABSTRAK
Penelitian ini bertujuan untuk: Menganalisis bentuk strategi kepala madrasah sebagai manajer dalam meningkatkan mutu madrasah di MI Wali Songo Asy-Syirbaany Tangerang Selatan. Penelitian ini menggunakan pendekatan kualitatif. Data dikumpulkan melalalui observasi dan wawancara kemudian dianalisis dengan menggunakan pendekatan Moleong dkk yaitu mengecek kebenaran data dari beberapa sumber yang dirasa memiliki pengetahuan yang baik terkait fokus penelitian yang diteliti. Hasil yang diperoleh dari penelitian ini, yaitu: Strategi kepala madrasah sebagai manajer dalam meningkatkan mutu madrasah, yaitu meliputi tiga hal yaitu input, proses, dan output. Input dalam artian adanya seleksi yang ketat bagi siswa baru dan guru yang ingin mengajar di MI Wali Songo Asyirbaany. Ketiga hal itu saling berkaitan satu sama lain, tanpa input dan proses pembelajaran yang bagus maka output yang dihasilkan oleh sebuah lembaga pendidikan juga tidak akan maksimal.
\end{abstract}

Kata Kunci: kepala madraah, manajer, mutu pendidikan

\section{PENDAHULUAN}

Mutu pendidikan belakangan ini kembali semakin banyak diperbincangkan, baik yang berskala nasional maupun lokal. Penyelengaraan pendidikan yang bermutu merupakan suatu keharusan untuk merespon tuntutan-tuntutan globalisasi. Dalam konteks ini, penting dicermati bahwa mutu pendidikan tidak hanya terbatas pada mutu hasil belajar peserta didik. Akan tetapi, mutu hasil belajar peserta didik tersebut merupakan gambaran mutu pendidikan yang dilatarbelakangi oleh banyak aspek yang mendorong tercapainya peningkatan mutu pendidikan. Aspek tersebut antara lain berupa input peserta didik maupun proses dalam penyelenggraan pendidikan tersebut. 
Komariah dan Triatna (2005: 6) bahwa pendidikan adalah investasi (investmen human capital) sehingga keberadaannya harus terkait kembali dengan hasil atau keluaran yang bermanfaat, menguntungkan secara finansial dan sosial. Apabila ditinjau dari sudut lulusan, output sekolah adalah lulusan yang berguna bagi kehidupan, yaitu lulusan yang bermanfaat bagi dirinya sendiri, keluarganya, dan lingkungannya, artinya lulusan ini mencakup outcome, yaitu hasil dari investasi pendidikan yang selama ini dijalani siswa untuk menjadi suatu yang berguna dan bermanfaat (benefit).

Menurut undang-undang nomor 20 tahun 2003 tentang Sistem Pendidikan Nasional, bahwa pendidikan adalah usaha sadar dan terencana untuk mewujudkan suasana belajar dan proses pembelajaran agar peserta didik secara aktif mengembangkan potensi dirinya untuk memiliki kekuatan spiritual, keagamaan, pengendalian diri, kepribadian, kecerdasan, akhlak mulia, serta keterampilan yang diperlukan dirinya, masyarakat, bangsa, dan negara (UUSPN, nomor 20 tahun 2003, pasal 1). Dengan demikian bahwa pendidikan adalah sebuah proses yang perlu direncanakan sebaik mungkin, agar mendapatkan hasil yang maksimal.

Menurut Sallis (2010: 56) mutu dapat didefinisikan sebagai sesuatu yang memuaskan dan melampaui keinginan dan kebutuhan pelanggan. Selanjutnya Juran dalam Hadis dan Nurhayati (2014: 84) mutu produk ialah kecocokan penggunaan produk untuk memenuhi kebutuhan dan kepuasan pelanggan.Crosby dalam Hadis dan Nurhayati (2014: 85) mutu yaitu sesuai dengan yang disyaratkan atau yang distandarkan. Suatu produk memiliki mutu apabila sesuai dengan standar atau kriteria mutu yang telah ditentukan. Menurut Fegenbaun dalam Hadis dan Nurhayati (2014: 85) mutu adalah kepuasan pelanggan sepenuhnya. Suatu produk dianggap bermutu apabila dapat memberikan kepuasan sepenuhnya kepada konsumen, yaitu sesuai dengan harapan konsumen atas produk yang dihasilkan oleh perusahaan. Dari beberapa definisi mutu di atas, maka bisa ditarik kesimpulan bahwa: (1) Mutu meliputi usaha memenuhi kebutuhan atau melebihi kebutuhan atau harapan pelanggan. 2) Mutu mencakup produk, jasa, manusia, proses, dan lingkungan. 3) Mutu merupakan kondisi yang selalu berubah misalnya apa yang dianggap merupakan mutu saat ini, mungkin dianggap kurang bermutu pada masa mendatang. Mutu bermanfaat bagi dunia pendidikan karena meningkatkan pertanggung jawaban suatu lembaga kepada masyarakat dan ataupemerintah yang telah memberikan semua biaya kepada lembaga tersebut, menjamin mutu lulusannya, bekerjalebih profesional, dan meningkatkan persaingan yang sehat. Selanjutnya terkait pengertian mutu pendidikan 
dapat dikatakan bahwa mutu pendidikan adalah keadaan sebuah lembaga pendidikan apakah memenuhi harapan atau keinginan masayarakat hingga masyarakat memperoleh kepuasan.

Dalam rangka untuk meningkatkan kualitas sumber daya manusia suatu bangsa tersebut maka diselenggarakan suatu sistem pendidikan nasional. Negara memberi kesempatan seluas-luasnya kepada setiap warga negara untuk mendapatkan pendidikan dan pengajaran. Dengan pendidikan dan pengajaran itu, diharapkan akan memperoleh pengetahuan dan kemampuan dasar sbagai bekal untuk dapat berperan serta dalam kehidupan masyarakat, berbangsa, dan bernegara.

Selain itu, Supriyatna (2007: 6) berpendapat bahwa pendidikan nasional harus mampu menjamin pemerataan kesempatan pendidikan, peningkatan mutu pendidikan, peningkatan relevansi pendidikan, dan peningkatan efisiensi manajemen pendidikan. Pemerataan kesempatan pendidikan diwujudkan dalam program wajib belajar Sembilan tahun. Peningkatan mutu pendidikan diarahkan untuk meningkatkan yang sesuai dengan tuntutan kebutuhan berbasis potensi sumber daya kualitas manusia Indonesia seutuhnya melalui olahhati, olahpikir, olahrasa, dan olahraga agar memiliki daya saing dalam menghadapi tantangan global. Oleh karena itu, menurut Soedijarto (2008: 474) bahwa demi mewujudkan dan tercapainya mutu atau kualitas pendidikan yang baik maka delapan standar nasional pendidikan yang telah ditetapkan oleh kemdiknas dengan PP no 10 tahun 2005 sekarang diganti PP no. 32 tahun 2013 yang meliputi standar isi, standar proses, standar kompetensi lulusan, standar pendidik dan tenaga kependidikan, standar sarana dan prasarana, standar pengelolaan, standar pembiayaan, dan standar penilaian pendidikan perlu diterapkan dan dilaksanakan secara hati-hati dan berdaya guna bagi mutu pendidikan secara merata.

Mutu pendidikan akan tercapai, apabila didukung oleh seluruh komponen dalam pendidikan yang terorganisir dengan baik. Akan tetapi, pada nyatanya di lapangan ditemukan dari beberapa hasil penelitian, menyatakan bahwa mutu pendidikan tergolong masih rendah dan kepala madrasah belum optimal dalam mengelola madrasah. Hal tersebut, dapat dilihat atas pernyataan pers hasil akreditasi sekolah/madrasah tahun 2019 .

Tabel 1.1

Data Akreditasi Sekolah/Madrasah

Tahun 2019

\begin{tabular}{|l|l|l|l|}
\hline No & Peringkat Akreditasi & Jumlah & Persentase \\
\hline
\end{tabular}




\begin{tabular}{|c|c|c|c|}
\hline 1 & Amat Baik (A) & 15.805 & $25.34 \%$ \\
\hline 2 & Baik (B) & 33.827 & $54.24 \%$ \\
\hline 3 & Cukup (C) & 11.317 & $18.15 \%$ \\
\hline 4 & Tidak terakreditasi & 116 & $2.27 \%$ \\
\hline
\end{tabular}

Berdasarkan table tersebut bahwa sekolah/madrasah yang telah diakreditasi yaitu: a) peringkat A sebanyak 15.805 (25,34\%), b) peringkat B sebanyak 33.827 (54,24\%), dan c) peringkat C sebanyak $11.317(18,15 \%)$, d) tidak terakreditasi sebanyak 116 (2,27\%) (BANS/M: 2019). Berdasarkan data tersebut dapat diduga bahwa masih banyak kepala sekolah/madrasah belum optimal dalam meningkatkan mutu pendidikan. Selanjutnya data laporan akhir pelaksanaan program akreditasi sekolah/madrasah DKI Jakarta tahun 2018 tingkat Madrasah Ibtidaiyah, yaitu: a) peringkat A sebanyak $58(48,70 \%)$, b) peringkat B sebanyak $54(45,40 \%)$, c) peringkat C sebanyak 4 (3,40\%), dan d) tidak terakreditasi sebanyak 3 (3,40\%) (BAN S/M DKI Jakarta: 2018). Berdasarkan data tersebut menunjukkan bahwa sekelas DKI Jakarta masih ada beberapa madrasah yang mendapatkan predikat akreditasi C bahkan ada beberapa madrasah yang tidak terakreditasi. Hal ini mengindikasikan bahwa belum optimalnya kinerja kepala madrasah dalam meningkatkan mutu pendidikan.

Peningkatan mutu pendidikan ditujukan untuk menciptakan sistem pendidikan yang mampu melayani kebutuhan masyarakat, serta menjamin dihasilkannya lulusan yang memenuhi harapan masyarakat. Selain itu, sistem pendidikan juga harus mampu menjamin pemerataan kesempatan pada peningkatan mutu serta relevansi dan efisiensi manajemen pendidikan untuk menghadapi tantangan sesuai dengan tuntutan perubahan kehidupan di dalam negeri maupun luar negeri. Sehingga diperlukan perubahan pendidikan secara terencana, terarah dan berkesinambungan. Oleh karena itu, pendidikan memerlukan penataan yang profesional, hal tersebut diperlukan personal yang mampu dan tangguh. Dari hal inilah yang kita sebut sebagai pemimpin pendidikan atau kepala madrasah. Seorang kepala madrasah tidak saja dituntut menguasai teori kepemimpinan akan tetapi juga harus terampil menerapkannya dalam setiap perubahan situasi dan kondisi.

Dalam suatu lembaga pendidikan yang sangat berperan penting sebagai suatu perubahan adalah pemimpin yang memimpin suatu lembaga tersebut. Hal ini terjadi karena pemimpinlah yang menjadi pengemudi kemana lembaga pendidikan tersebut akan dibawanya. Yukl (2001: 3) mendefinisikan bahwa kepemimpina berkaitan dengan proses 
yang disengaja dari seseorang untuk menekankan pengaruhnya yang kuat terhadap orang lain, untuk membimbing, membuat struktur, memfasilitasi aktivitas dan hubungan di dalam kelompok atau organisasi. Machali dan Hidayat (2018: 84), mendefinisikan bahwa kepemimpinan (leadership) adalah kemampuan untuk menggerakkan, mempengaruhi, memotivasi, mengajak, mengarahkan, menasihati, membina, membimbing, melatih, memerintah, melarang, dan bahkan menghukum (bila perlu) dengan maksud agar manusia sebagai bagian dari organisasi mau bekerja dalam rangka mencapai tujuan dirinya sendiri maupun organisasi secara efektif dan efisien.

Engkoswara dan Komariah (2012: 178) berpendapat bahwa kepemimpinan adalah suatu proses mempengaruhi, mengkoordinasi, dan menggerakan perilaku orang lain serta melakukan suatu perubahan ke arah yang lebih positif dalam mengupayakan suatu keberhasilan.

Selanjutnya menurut Usman (2013: 312) kepemimpinan merupakan ilmu dan seni mempengaruhi orang atau kelompok untuk bertindak seperti yang diharapkan untuk mencapai tujuan secara efektif dan efisien.

Berdasarkan beberapa definisi tersebut dapat ditarik kesimpulan bahwa kepemimpinan memiliki peran yang sangat penting dalam rangka mengarahkan dan menggerakkan organisasi pendidikan untuk mencapai tujuan yang diharapkan.

Selanjutnya kepala madrasah menurut Kamus Besar Bahasa Indonesia, bahwa istilah kepala madrasah terdiri atas dua kata, yaitu "kepala" dan "madrasah", kata kepala dapat diartikan sebagai pimpinan tau ketua dalam suatu organisasi atau sebuah lembaga. Sedangkan madrasah merupakan sebuah lembaga pendidikan Islam di mana menjadi tempat menerima dan memberi pelajaran.Dalam Al-Munjid seperti yang dikutip Muhaimin (2007: 183) mendefinisikan sekolah dalam bahasa Arab yaitu madrasah. Madrasah adalah isim makan dari kata: darasa-yadrusu-darsan wa durusan wadirasan yang berarti: terhapus, hilang bekasnya, menghapus, menjadikan usang, melatih, mempelajari. Dilihat dari pengertian ini, maka madrasah berarti merupakan tempat untuk mencerdaskan para peserta didik, serta melatih ketrampilan mereka sesuai dengan bakat, minat dan kemampuan.

Madrasah pada umumnya dipandang sebagai tempat untuk mengkaji ilmu pengetahuan agama. Namun sesuai dengan perkembangan zaman madrasah sudah mulai berbenah diri, dengan mencantumkan kurikulum yang diluar pendidikan agama, misalkan memuatkan mata pelajaran ilmu pengetahuan alam, matematika dan lain-lain. Hal ini 
dilakukan untuk dapat bersaing dengan sekolah atau madrasah lain agar tetap survive. Muhaimin (2007: 187) madrasah pada dasarnya merupakan: (1) Lembaga pendidikan yang berbasis masyarakat, yakni menyelenggarakan pendidikan berdasarkan kekhasan agama Islam serta sosial, budaya, aspirassi dan potensi masyarakat islam, sebagai perwujudan pendidikan dari, oleh, dan untuk masyarakat islam. (2) Pendidikan umum yakni merupakan pendidikan dasar (MI dan MTs) dan menengah (MA) yang mengutamakan perluasan pengetahuan yang diperlukan oleh peserta didik untuk melanjutkan pendidikan yang lebih tinggi, dan atau/ untuk hidup dimasyarakat, (3) Pendidikan keagamaan, yakni merupakan pendidikan dasar dan menengah yang mempersiapkan peserta didik untuk dapat menjalankan peranan yang menuntut penguasaan dan pengamalan nilai-nilai dan ajaran agama Islam.

Sementara itu, menurut PMA 58 tahun 2017 tentang kepala madrasah bahwa kepala madrasah melaksanakan tugas manajerial, mengembangkan kewirausahaan, dan melakukan supervisi kepada guru dan tenaga kependidikan. Selain melaksanakan tugas tersebut, kepala madrasah dapat melaksanakan tugas pembelajaran atau pembimbingan untuk memenuhi kebutuhan guru madrasah.

Jadi dapat disimpulkan bahwa kepemimpinan kepala madrasah merupakan seseorang yang diberi tugas untuk memimpimpin suatu lembaga madrasah dimana di dalam madrasah tersebut diselenggarakan kegiatan proses belajar mengajar. Kemudian di dalam menjalankan tugasnya seorang pemimpin madrasah harus bertanggung jawab terhadap kualitas lembaga yang dipimpinnya dengan tujuan tercapainya tujuan pendidikan yang telah ditetapkan.

Machali dan Hidayat (2018: 109) berpendapat bahwa seorang kepala madrasah harus memiliki keterampilan dasar manajerial, yaitu: (1) keterampilan teknis (technical skill). Keterampilan yang berhubungan dengan pengetahuan, metode, dan teknik-teknik tertentu dalam menyelesaikan suatu tugas-tugas tertentu.Dalam praktiknya, keterlibatan seorang pemimpin dalam setiap bentuk technical skill disesuaikan dengan status atau tingkatan pemimpin itu sendiri. (2) Keterampilan manusia (human skill). Keterampilan yang menunjukkan kemampuan seorang pemimpin di dalam bekerja melalui orang lain secara efektif dan untuk membina kerjasama. (3) Keterampilan konseptual (conceptual). Keterampilan terakhir ini menunjukkan kemampuan dalam berpikir, seperti menganalisis suatu masalah, memutuskan, dan memecahkan masalah tersebut dengan baik. Untuk dapat menerapkan keterampilan-keterampilan ini seorang pemimpin dituntut memiliki 
pemahaman yang utuh (secara totalitas) terhadap organisasinya. Tujuannya agar dapat bertindak selaras dengan tujuan organisasi secara menyeluruh atas dasar tujuan dan kebutuhan kelompok sendiri.

Semetara itu menurut Rosyada (2017: 189) tugas kepala madrasah sebagai manajer, sangat kompleks, tidak sekedar mengelola kurikulum dan buku ajar, tetapi juga sumber daya guru, staf tata usaha dan juga mengelola serta mengembangkan aset dan mengelola keuangan lembanganya. Dengan demikian kepala madrasah harus memiliki kecerdasan professional, kecerdasan personal, dan kecerdasan manajerial. Terkait kecerdasan manajerial, bahwa seorang kepala madrasah harus memiliki ide-ide besar untuk kemajuan madrasahnya, mampu mengorganisasi seluruh stafnya untuk melaksanakan program yang sudah direncanakan sebagai rencana kerja tahunan, mampu memberikan motivasi kepada seluruh staf akademik dan staf non akademik, dan selalu menghargai seluruh stafnya itu. Seorang kepala madrasah harus mampu berkomunikasi dengan baik untuk membuat seluruh stafnya memahami sesuatu yang harus mereka kerjakan dan mampu mendorong meraka untuk bekerja memajukan institusi madrasahnya. Dan bahkan seorang kepala madrasah harus mampu mengevaluasi secara objektif pekerjaan yang diselesaikan oleh seluruh kelompok kerjanya dan menjadikan sebagai inspirasi untuk perbaikan di waktu mendatang.

Selanjutnya menurut Daryanto dalam asmani (2012: 26) peran kepala madarsah sebagai manajer, yaitu: (1) Bidang kelembagaan mencakup: anggaran madarsah, perawatan madrasah, inventaris sumber daya materi madrasah, penyelesaian semua format dan laporan, dan pengumpulan data. (2) Bidang kurikulum mencakup: pengaturan kelas, pembelajaran materi-materi untuk kelas, jam pelajaran di madrasah, kegiatan ekstrakurikuler. (3) Bidang sumber daya manusia mencakup: materi dan peralatan untuk guru, akomodasi guru, pemilihan komite madrasah, pemilihan pemimpin di kalangan siswa, pengorganisasian siswa, beban dan tanggung jawab menagajar. (4) bidang budaya dan masyarakat mencakup: mengatur rapat komite madrasah, menyelesaikan rencana kerja madrasah, melatih komite madrasah menyelenggarakan rapat yang efektif, dan melatih badan pengurus komite madrasah dalam menjalankan perannya.

Berdasarkan beberapa pendapat tersebut bahwa kepala madrasah sebagai manajer harus memiliki beberapa keterampilan antara lain yaitu keterampilan teknis, konseptual, dan emosional. Kepala madrasah bertanggung jawab terhadap maju mundurnya satuan pendidikan yang menjadi wilayah otoritasnya, yang paling pertama harus dilakukannya 
adalah merumuskan visi kepemimpinannya, mempersiapkan madrasah yang layak untuk menyelenggrakan pendidikan dan pembelajaran, bersikap sebagai seorang pemimpin di hadapan seluruh staf akademik dan non akademik, dan mengoptimalkan layanan seluruh stafnya untuk mempercepat kemajuan. Dan bersamaan dengan itu, kepala madrasah juga harus terus malakukan analisis terhadap bebagai aspek agar tercapai visi yang telah ditentukan.

Kepala madrasah merupakan pimpinan pendidikan yang mempunyai peranan penting dalam mengembangkan lembaga pendidikan, yaitu sebagai pemegang kendali dilembaga pendidikan. Dalam hal ini, peranan kepala madrasah harus digerakkan sedemikian rupa sesuai dengan perannya dalam meningkatkan mutu pendidikan yaitu sebagai manajer sehingga dapat mempengaruhi kalangan guru dan tenaga kependidikan, baik itu secara langsung maupun tidak langsung. Di samping itu, kepala madrasah juga mempunyai peranan yang sangat besar dalam mengembangkan kualitas pendidikan di lembaga pendidikan tersebut. Sejalan dengan itu, peranan kepala madrasah sangat berpengaruh dalam pertumbuhan dan perkembangan pendidikan yaitu untuk meningkatkan sumber daya manusia dan mutu pendidikan. Kepala madrasah dan guru beserta tenaga kependidikan lainnya dituntut untuk berperan aktif untuk meningkatkan pertumbuhan dan perkembangan kualitas profesinya dengan harapan memperoleh pengetahuan baru.

Kepala madrasah juga bertindak sebagai seorang pendidik yang bertanggung jawab terhadap manajemen madrasah. Keberhasilan suatu lembaga pendidikan sangat tergantung pada kepemimpinan kepala madrasah. Karena kepala madrasah sebagai pemimpin di lembaganya, maka kepala madrasah harus mampu membawa lembaganya kearah tercapainya yang telah ditetapkan. Kepala madrasah harus mampu melihat adanya perubahan serta mampu melihat masa depan dalam kehidupan globalisasi yang lebih baik. Kepala madrasah harus bertanggung jawab atas kelancaran dan keberhasilan semua urusan pengaturan dan pengelolahan secara formal kepada atasannya atau informal kepada masyarakat yang telah menitipkan anak didiknya.

Sistem pendidikan madrasah merupakan produk kreativitas intlektual muslim sebagai bentuk pembaharuan atas lembaga pendidikan Islam yang ada sebelumnya. Tujuannya agar dapat menjawab tantangan dan tuntutan di zaman yang semakin kompleks, mendesak dan tidak dapat dihindari lagi. Terlepas dari problem yang dihadapi, baik yang berasal dari dalam sistem seperti masalah manajemen, kualitas input dan kondisi sarana dan prasarana, maupun dari luar sistem seperti persyaratan akreditasi yang kaku dan aturan- 
aturan lain. Madrasah yang memiliki karakteristik yang khas yang tidak dimiliki oleh lembaga pendidikan lain menjadikan harapan bagi manusia.

Praktik manajemen di madrasah sering menunjukkan model manajemen tradisional. Dominasi senioritas semacam dalam manajemen madrasah sangat mengganggu perkembangan dan peningkatan mutu pendidikan di madrasah. Dalam bidang manajemen madrasah, masih banyak ditemukan bahwa tidak optimalnya peran serta pengelola madrasah dalam menjalankan prinsip-prinsip manajemen dalam pelaksanaan proses belajar mengajar, pengambilan keputusan, pelaksanaan kurikulum dan aktivitas kurikuler lainnya. Selain itu penerapan prinsip-prinsip manajemen seperti bagaimana penerapan planning, organizing, controlling dan evaluating belum dijalankan sepenuhnya.

Selanjutnya menurut Nata (2012: 309) behawa penyebab mutu madrasah menjadi rendah, antara lain disebabkan oleh; (1) karena pengelolaan madrasah terlalu di dominasi oleh kalangan umat Islam teradisonal dan konservatif. Mereka cenderung memahami Islam sebagai agama semata-mata, dan karenanya menganggap ilmu pengetahuan dan teknologi sebagai yang bukan urusan Islam, dan karenanya tidak perlu diajarkan kepada masyarakat.(2) karena pada umumnya madrasah belum memenuhi kebutuhan finansial secara mandiri. Akibat dan kekurangan finansial ini, mereka tidak mampu mengadakan berbagai sarana dan prasarana pendidikan yang diperlukan, tidak mampu membayar gaji guru secara layak dan tidak mampu melakukan perencanaan, serta tidak dapat menerapkan metode dan strategi pembelajaran yang lebih variatif dan berbasis pada pembelajaran para siswa.(3) karena pada umumnya madrasah belum memiliki visi, misi, dan tujuan yang jelas. Dengan demikian kegiatan madrasah berjalan apa adanya, tanpa arah dan tanpa tujuan yang jelas, serta pada umumnya madrasah belum memilki program dan target yang hendak dicapai. Madrasah pada umumnya dikelola dengan manajemen keluarga.

Rendahnya mutu pendidikan di Indonesia disinyalir dipengaruhi oleh beberapa faktor. Bila melihat dari segi fasilitas, masih terdapat madrasah yang kondisi sarana dan prasarananya tidak mendukung. Kemudian masih terdapat sumber daya manuisa yang kurang professional. Sumber daya manusia dalam hal ini yaitu tenaga pendidik dan tenaga kependidikan. Tenaga pendidik dan tenaga kependidikan memiliki peranan penting dalam hal peningkatan mutu sebuah madrasah. Selain profesionalisme guru, kurangnya kesejahteraan guru dalam kaitannya dengan peningkatan mutu madrasah. Proses pembelajaran yang tidak berjalan efektif juga menjadi salah satu faktor yang 
mempengaruhi peningkatan mutu pendidikan di sebuah madrasah. Kemudian, masih banyak program-program sekolah yang belum tercapai.

Berbeda halnya dengan MI Wali Songo Asy-Syirbaany Tangerang Selatan. Peningkatan mutu pendidikan di MI Wali Songo Asy-Syirbaany didorong oleh berbagai faktor pendukung, yaitu mulai dari kepala madrasah, guru, siswa, hingga para stakeholder atau para pihak yang berkepentingan. Pihak-pihak yang berkepentingan tersebut antara lain seperti orang tua siswa, yayasan, dan komite. Selain itu komunikasi dan kerjasama dua arah dari berbagai pihak juga mempengaruhi peningkatan mutu di Wali Songo AsySyirbaany, sebab dengan faktor tersebut, semua pihak dapat menentukan tujuan yang diinginkan. Peningkatan mutu pendidikan erat kaitannya dengan proses kegiatan belajar mengajar, dimana dalam proses kegiatan belajar mengajar yang memegang peranan penting adalah guru. Guru yang berkualitas akan menghasilkan output yang berkualitas pula. Kehadiran guru yang kurang disiplin dan masih ada guru yang merangkap jabatan bisa menjadi salah satu faktor penyebab kurang optimalnya peningkatan mutu pendidikan

Berdasarkan paparan tersebut, maka penulis merasa tertarik untuk mengadakan penelitian tentang "Peranan Kepemimpinan Kepala Madrasah Sebagai Manajer dalam Meningkatkan Mutu Pendidikan (Studi Kasus Tentang Manajmen Kepala Madrasah di MI Wali Songo Asy-Syirbaany Tangerang Selatan)".

\section{METODE PENELITIAN}

Metode yang digunakan pada studi ini adalah pendekatan penelitian kualitatif. Menurut bogdan dan Taylor, seperti dikutip Moleong (2002: 4), definisi pendekatan penelitian kualitatif adalah prosedur penelitian yang menghasilkan data deskriptif berupa kata-kata tertulis atau lisan dari orang-orang dan perilaku yang dapat diamati. Menurut Deddy Mulyana (2001: 150) metode penelitian kualitatif, yaitu jenis metode penelitian yang tidak mengandalkan bukti berdasarkan logika matematis, prinsip angka, atau metode statistik dan bertujuan mempertahankan bentuk dan isi perilaku manusia dan menganalisis kualitas-kualitasnya. Anselm Strauss dan Juliet Corbin (2009: 4) berpendapat, bahwa penelitian kualitatif, yaitu jenis penelitian yang temuan-temuannya tidak diperoleh melalui prosedur statistik atau bentuk hitungan lainnya. Jadi dalam penelitian ini, akan menjelaskan dan mengungkapkan kepemimpinan kepala madrasah sebagai manajer dalam meningkatkan mutu di MI Wali Songo Asy-Syirbaany Tangerang Selatan. 
Guna menemukan tujuan penelitian di atas, Peneliti dalam melakukan uji validitas data penelitian ini, yaitu dengan pengukuran derajat kepercayaan data. Adapun teknik yang digunakan dalam uji ini, adalah dengan triangulasi. Menurut Moleong triangulasi adalah teknik pemeriksaan keabsahan data yang memanfaatkan sesuatu yang lain (Moleong, 2017: 330). Triangulasi yang dilakukan dalam penelitian ini adalah, triangulasi sumber yaitu mengecek kebenaran data dari beberapa sumber yang dirasa memiliki pengetahuan yang baik terkait fokus penelitian yang diteliti, teknik ini digunakan dalam penelitian kepemimpinan kepala sekolah dalam meningkatkan mutu sekolah di MI Wali Songo Asy-Syirbaany Tangerang Selatan. Kemudian, triangulasi teknik dilakukan dengan sumber yang sama, data dicek dengan teknik wawancara, teknik observasi, dan studi dokumentasi.

\section{PEMBAHASAN}

\section{Propil Mi Wali Songo Asy-Syirbaany}

Madrasah Ibtidaiyah Wali Songo Asy-Syirbaany secara geografis terletak di Jl. Betawi Kampung Gunung Kali Mati RT. 05 RW. 16 No. 87 Kelurahan Jombang Kecamatan Ciputat Kota Tangerang Selatan Provinsi Banten. Madrasah Ibtidaiyah ini, memiliki izin operasional pada tahun 2013 berdasarkan surat keputusan kepala kantor Kementerian Agama Kota Tangerang Selatan Nomor: Kd.28.08/4/PP.03.2/535/2013. Kurikulum yang digunakan Madrasah Ibtidaiyah Wali Songo Asy-Syirbaany ini, menggunakan kurikulum 2013 pada setiap jenjang kelasnya, mulai dari kelas I sampai dengan kelas VI. Walaupun tergolong madrasah baru, MI Wali Songo Asy-Syirbaany sudah terakreditasi predikat baik dengan nilai akhir 86 berdasarkan Badan Akreditasi Nasional sekolah/Madrasah (BAN-S/M) berdasarkan SK Penetapan Hasil Akreditasi BAP-S/M pada tangal 12 November 2017 Nomor: 120/BAP-S/M-SK/XI/2017. MI Wali Songo Asy-Syirbaany merupakan salah satu pilihan MI di Kota Tangerang Selatan, hampir setiap tahun dalam penerimaan peserta didik baru selalu menolak siswa.

Akses jalan menuju MI Wali Songo Asy-Syirbaany sangat strategis. Dari arah Stasiun Ketera Api Sudimara mengikuti arah jalur menuju Jl. H. Bolot Kelurahan Jombang-Ciputat. MI Wali Songo Asy-Syirbaany tepat berada di samping Masjid Nurul Yaqin, dimana masjid ini merupakan masjid tertua di daerah kampung Gunung Kelurahan Jombang-Ciputat. Melihat begitu pesatnya kemajuan Ilmu Pengetahuan dan Teknologi serta begitu beragamnya kasus kenakalan remaja maupun kriminalitas yang terjadi pada 
anak-anak maupun remaja, pengelola merasa perlu untuk mendirikan sebuah lembaga pendidikan Islam yang unggul dalam pengetahuan umum namun berimbang dengan iman, taqwa serta berakhlakul karimah. Awal didirikan Madrasah ini hanya berbentuk Madrasah Diniyah yang terfokus kepada Pengetahuan Agama berupa Nahwu dan Sorof kemudian seiring dengan berjalannya waktu kemudian Madrasah Diniyah Wali songo ini berkembang menjadi Madrasah Ibtidaiyah yang begitu diminati oleh penduduk sekitar.

Pengurus yayasan yang membina langsung MI Wali Songo melihat perlu adanya pendidikan yang lebih formal bukan hanya sekadar pendidikan diniyah. Akhirnya diusulkanlah untuk membuat Madrasah Ibtidaiyah dengan rencana awal membangun satu gedung dengan 8 lokal. Proses pembangunan terus berlanjut sampai pada akhirnya MI Wali Songo Asy-Syirbaany pada tahun 2019 sudah memiliki tiga gedung dengan 18 lokal ruang kelas. MI Wali Songo Asy-Syirbaany Kota Tangerang Selatan saat ini sudah meluluskan 3 angkatan dan perkembangannya semakin pesat berkat keandalan dengan menerapkan konsep kitab kuning dalam kurikulum muatan lokal yang sangat menarik minat para orang tua untuk menyekolahkan anaknya yang didukung dengan berbagai kelebihan salah satunya dengan kelas yang didesign modern dengan kapasitas maksimal hanya 24 siswa. Selain itu kurikulum pembelajaran yang inovatif dan kental dengan keagamaan juga menjadi salah satu daya pikat MI Wali Songo sehingga yang tadinya siswa hanya berasal dari lingkungan sekitar kini mulai merambat ke wilayah berbeda kelurahan bahkan berbeda kecamatan.

\section{Deskripsi dan Analisa Data}

Berdasarkan wawancara dengan responden yang dilengkapi dengan hasil observasi dan studi dokumentasi maka diperoleh hasil penelitian bahwa Kepala madrasah merupakan tenaga kependidikan yang paling strategis untuk menggerakkan garda terdepan dalam system pendidikan nasional. Rekruitmen Kepala Madrasah di MI Wali Songo Asy-Syirbaany berdasarkan pengalaman mengajar dan tentunya penunjukan langsung oleh pengurus yayasan. Adapun periode kepemimpinan Kepala Madrasah di MI Wali Songo Asy-Syirbaany sama dengan madrasah-madrasah pada umumnya yaitu lima tahun. Banyak hal yang menjadi pertimbangan dari pengurus yayasan, di antaranya yaitu kemampuan manajerial seorang guru, komitmen dalam mengajar, etika serta nilai-nilai keislamannya baik, serta dapat mengambil keputusan. Dalam proses pengangkatan Kepala Madrasah, pengurus yayasan kembali menempuh jalan musyawarah mufakat. Sedangkan untuk pemberhentian Kepala Madrasah berdasarkan hasil musyawarah besar pengurus. 
Pemberhentian Kepala Madrasah tidak pernah terjadi di MI Wali Songo Asy-Syirbaany, yang terjadi hanya pengunduran diri oleh Kepala Madrasah yang disebabkan oleh beberapa hal. Di antaranya sakit serta pengunduran diri yang disebabkan oleh perasaan tidak percaya diri atas kemampuan dirinya dalam memimpin sebuah Madrasah. Pengurus yayasan sendiri tidak pernah melayangkan surat keputusan pemberhentian bagi Kepala Madrasah MI Wali Songo Asy-Syirbaany Kota Tangerang Selatan.

Strategi Kepala Madrasah dalam Meningkatkan Mutu Pendidikan MI Wali songo Asy-Syirbaany yaitu Menurut kepala madrasah MI Wali Songo Asy-Syirbaany kegiatan yang sudah dilaksanakan dalam meningkatkan mutu pendidikan MI Wali Songo AsySyirbaany, yaitu pengembangan input madrasah seperti pendidik. Peningkatan mutu dari sisi tenaga pendidik yaitu dengan mengembangkan kemampuan mereka melalui pelatihanpelatihan seperti seminar kurikulum 2013 yang bekerja sama dengan penerbit Kemdikbud dan Kemenag. Pengarahan tentang perlindungan anak dan pelatihan membaca atau tilawah yang kemudian akan diterapkan pula kepada peserta didik di MI Wali Songo AsySyirbaany. Pengembangan kemampuan membaca kitab kuning kepada tenaga pendidik yang dilakukan oleh kepala madrasah. Selanjutnya, dari sisi peserta didik peningkatan mutu dilakukan dengan melakukan seleksi yang cukup ketat khusunya bagi calon siswa pada saat penerimaan peserta didik baru. Seleksi yang dilakukan yaitu menulis, membaca, tes kematangan, serta wawancara orang tua. Semua hal tersebut dilakukan semata-mata untuk mendapatkan input yang baik sehingga akan tercipta proses yang efesien dan efektif menghasilkan output sesuai dengan visi dan misi madrasah. Selain itu, kegiatan-kegiatan yang telah dilaksanakan oleh kepala madrasah dalam meningkatkan mutu pendidikan MI Wali Songo Asy-Syirbaany antara lain dengan aktif dalam berbagai kegiatan baik di dalam madrasah maupun luar madrasah. Selain itu melaksanakan beberapa kegiatan yang bertujuan untuk mengembangkan kemampuan anak baik dalam bidang akademis maupun non akademis. Antara lain, yaitu peningkatan mutu dalam keagamaan bidang membaca Al-Quran serta membaca kitab-kitab kuning. Hal ini lah yang menjadi kepercayaan masyarakat terhadap MI Wali Songo Asy-Syirbaany. Dimana orang tua ingin menyekolahkan anaknya di MI Wali Songo Asy-Syirbaany dengan tujuan anaknya agar bias membaca Al-Quran dengan baik dan mampu membaca kitab-kitab klasik agar menjadi bekal dalam kehidupannya dan dalam bermasyarakat. Berdasarkan pemaparan di atas, maka dapat disimpulkan bahwa sangat banyak manfaat yang dirasakan dari usaha kepala madrasah dalam peningkatan mutu pendidikan. Manfaat tersebut dirasakan hampir 
oleh setiap guru dan tenaga kependidikan di MI Wali Songo Asy-Syirbaany. Pelatihan maupun seminar yang dilakanakan oleh pengurus yayasan dan kepala madrasah berdampak pada meningkatnya kempuan guru-guru di MI Wali Songo Asy-Syirbaany, kualitas kegiatan belajar dan mengajar menjadi lebih kreatif dan inovatif, adanya dampak positif yang dirasakan oleh peserta didik, serta membuat MI Wali Songo Asy-Syirbaany menjadi lebih dipercaya masyarakat, baik masyarakat sekitar maupun masyarakat lainnya di luar wilayah MI Wali Songo Asy-Syirbaany.

\section{Temuan Hasil Penelitian}

Dari hasil penelitian yang diperoleh penulis maka dapat diketahui ada beberapa hal yang dapat dipahami bahwa dalam meningkatkan mutu pendidikan dibutuhkan campur tangan seluruh pihak penyelenggara pendidikan khususnya pemangku jabatan tertinggi. Dalam sebuah pendidikan yang memiliki beberapa sub satuan pendidikan yang memegang peranan penting adalah kepala madrasah. Menurut penulis, peran kepala madrasah dalam peningkatan mutu pendidikan yaitu: (1) Penentu kebijakan: kebijakankebijakan yang direncanakan oleh kepala madrasah beserta jajarannya di setiap satuan pendidikan tentunya harus berdasarkan persetujuan dari pengurus yayasan. (2) Pengambil keputusan: dalam hal rekruitmen, mutasi, pengangkatan jabatan kepala madrasah, yayasan merupakan pihak pengambil keputusan tertinggi. Diterima atau tidaknya calon pendidik di satuan pendidikan, kriteria pengangkatan kepala madrasah, pemberhentian seorang karyawan, sampai dengan mutasi seorang guru atau tenaga pendidik. (3) Pembimbing, pengarah, pembina, dan penasehat: untuk mendukung tercapainya visi dan misi MI Wali Songo Asy-Syirbaany, pengurus kepala madrasah memiliki peranan membimbing, mengarahkan dan membina kepala madrasah, para pendidik dan tenaga kependidikan. Selain itu juga kepala madrasah berperan sebagai penasehat atas segala kebijakan dan langkah yang hendak diambil oleh kepala madrasah dalam menjalankan roda pendidikan dan juga dalam mencapai visi dan misi MI Wali songo Asy-Syirbaany.

Kepemimpinan kepala madrasah MI Wali Songo Asy-Syirbaany merupakan kepemimpinan demokratis karismatis dimana kepala madrasah selalu mengadakan musyawarah kepada seluruh dewan guru, staf dan tata usaha dalam menetapkan setiap keputusan yang akan diambil. Kepemimpinan kepala madrasah sangat bijaksana dan bertanggung jawab yaitu bijaksana dalam hal memberikan keputusan kemudian menyelesaikan sebuah masalah dan bertanggung jawab dalam kepemimpinannya. Kepala madrasah telah menjalankan peran kepemimpinannya secara baik itu tercermin dari iklim 
kerja yang menyenangkan. Kepala madrasah tidak memberikan batasan atau perbedaan antara kepala madrasah dengan seluruh dewan guru, staf dan tata usaha mereka semua berbaur menjadi satu kesatuan.

Mutu pendidikan di MI Wali Songo Asy-Syirbaany sudah memenuhi 8 Standar Nasioanal Pendidikan. Pelaksanaan kurikulum di MI Wali Songo Asy-Syirbaany sudah menggunakan kurikulum 2013. Kemudian dari kompetensi guru dalam mengajar sudah cukup baik, RPP dan silabus sudah dipersiapkan guru sebelum memulai pembelajaran. MI Wali Songo Asy-Syirbaany dalam pengadaan sarana dan prasarana hanya $90 \%$ yang sudah memadai untuk menunjang pembelajaran peserta didik. MI Wali Songo AsySyirbaany telah banyak meraih prestasi. Prestasi tersebut dapat dilihat dari mutu/kualitas peserta didik MI Wali Songo Asy-Syirbaany yang sudah banyak meraih juara seni tilawah.

Peran kepala madrasah dalam meningkatkan mutu pendidikan di MI Wali Songo Asy-Syirbaany ialah dengan mengaplikasikan program-program yang telah direncanakan dan disusun oleh kepala madrasah. Dalam mengevaluasi program mutu pendidikan kepala madrasah memiliki catatan sebagai evaluasi sejauh mana keberhasilan atau kegagalan madrasah dan untuk mengantisipasi bentuk-bentuk kegagalan tersebut kepala madrasah melakukan evaluasi satu kali dalam seminggu terhadap program kerja yang dilaksanakan oleh peserta madrasah baik terhadap guru, tenaga kependidikan maupun peserta didik, kemudian kepala madrasah selalu melakukan monitoring di dalam kelas untuk mengetahui sejauhmana perkembangan-perkembangan di dalam kelas untuk mencapai visi misi dan untuk terlaksananya program mutu. Peran kepemimpinan yang dijalankan kepala madrasah untuk meningkatkan mutu pendidikan di MI Wali Songo Asy-Syirbaany, yaitu sebagai: edukator, manager, administator, supervisor, leader, inovator, motivator. Peran kepemimpinan kepala madrasah dalam meningkatkan mutu madrasah dengan menjalankan beberapa program kerja, yaitu: a) menjabarkan visi ke dalam misi untuk mencapai target mutu dengan memberikan penghargaan atau hadiah kepada peserta didik yang berprestasi; melaksanakan sholat duha bersama dan dzuhur berjamaah di mesjid yang dekat dengan madrasah; melaksanakan beberapa program ekskul setiap hari sabtu untuk kegiatan pramuka, praktek bahasa inggris dan bahasa arab, mengadakan acara pada hari-hari besar islam, seperti isra' mi'raj dan maulid nabi dengan mendatangkan ustadz untuk memberikan ceramah kepada siswa dan siswi; b) Kepala madrasah merumuskan tujuan dan target mutu yang akan dicapai dengan membuat rencana program kinerja 
jangka pendek, jangka menengah dan jangka panjang untuk satu tahun kedepan; c) Menganalisis tantangan, peluang, kekuatan dan kelemahan madrasah; d) Dalam membuat keputusan anggaran madrasah kepala madrasah bermusyawarah dengan pihak yayasan; e) Melibatkan dewan guru dan tata usaha dalam pengambilan keputusan penting madrasah; f) Memberikan dan meningkatkan motivasi kerja pendidik dan tenaga kependidikan dengan menggunakan sistem pemberian penghargaan pada guru berprestasi, serta meningkatkan motivasi siswa dalam belajar dengan memberikan hadiah bagi siswa berprestasi; g) Menjalankan fungsinya sebagai motivator dengan cara mengevaluasi kinerja pengelola madrasah secara rutin setiap minggunya, penanaman kerjasama tim yang baik, selalu bermusyawarah kepada guru yaitu musyawarah yang sifatnya saling memberikan masukan dengan menganggap guru sebagai rekan kerja dan memberikan support kepada guru agar menjalankan kinerjanya dengan baik.

Mencermati hasil temuan di atas dapat dijelaskan bahwa peran kepemimpinan kepala madrasah dalam meningkatkan mutu pendidikan dapat dilakukan dengan mengupayakan peningkatan sumber daya manusia di madrasah yaitu, dengan mengupayakan peningkatan kinerja guru dengan cara membuat pelatihan yang dilaksanakan, mengupayakan peningkatan kinerja masing-masing pengelola madrasah dengan mengevaluasi kinerja dan pencapaian target dengan cara membuat agenda rapat rutin internal madrasah, serta mengupayakan peningkatan prestasi siswa di madrasah. Sumber daya manusia di madrasah merupakan unsur penting dalam sebuah organisasi pendidikan. Apabila gurunya berkualitas maka akan menghasilkan peserta didik yang berkualitas pula, begitu juga dengan pengelola madrasah apabila kinerja masing-masing pengelola madrasah sudah optimal maka kegiatan dan pelaksanaan di madrasah akan berjalan efektif. Maka dari itu, agar guru dan masing-masing pengelola madrasah semangat kerja dan terus meningkatkan kinerjanya, maka pihak madrasah membuat penilaian sebagai hadiah berupa kenaikan gaji melalui berbagai level.

Peran kepemimpinan kepala madrasah dalam meningkatkan mutu pendidikan di MI Wali Songo Asy-Syirbaany juga dapat dilakukan dengan cara mengupayakan berbagai kegiatan di madrasah, yaitu melakukan pengembangan ekskul dengan cara memberikan formulir minat dan bakat kepada peserta didik untuk menentukan ekskul apa yang akan diikuti setiap tahun ajaran baru, membuat agenda rapat rutin internal sebagai bahan intropeksi dan perbaikan secara terus-menerus, menerapkan disiplin yang tidak membuat anak tertekan, menumbuhkan karakter keislaman melalui berbagai perayaan hari besar 
agama islam. Oleh karena itu, untuk merealisasikan kebijakan tersebut, maka madrasah perlu melakukan manajemen peningkatan mutu.

\section{KESIMPULAN}

Berdasarkan hasil penelitian yang dilaksanakan di MI Wali Songo Asy-Syirbaany dapat diambil kesimpulan bahwa Strategi kepala madrasah sebagai manajer dalam meningkatkan mutu madrasah, yaitu meliputi tiga hal yaitu input, proses, dan output. Input dalam artian adanya seleksi yang ketat bagi siswa baru dan guru yang ingin mengajar di MI Wali Songo Asyirbaany. Ketiga hal itu saling berkaitan satu sama lain, tanpa input dan proses pembelajaran yang bagus maka output yang dihasilkan oleh sebuah lembaga pendidikan juga tidak akan maksimal.

\section{DAFTAR PUSTAKA}

Arifin, Z. (2012). Penelitian Pendidikan Metode dan Paradigma Baru. Bandung: PT Remaja Rosdakarya.

Arikunto, S. (2013). Prosedur Penelitian suatu Pendekatan Praktik. Jakarta: PT Rineka Cipta.

Asmani, J. M. (2012). Tips menjadi Kepala Sekolah Profesional. Yogyakarta: DIVA Press.

Asmani, J. M. (2015). Manajemen Efektif Marketing Sekolah Strategi Menerapkan Jiwa Kompetisi dan Sportivitas untuk Melahirkan Sekolah Unggulan. Yogyakarta: DIVA Press.

Azra, A. (2014). Pendidikan Islam Tradisi dan Modernisasi di Tengah Tantangan Milenium III. Jakarta: Kencana Prenadamedia Group.

Baedowi, A. (2015). Manajemen Sekolah Efektif. Jakarta: PT Pustaka Alvabet.

Bafadal, I. (2012). Manajemen Peningkatan Mutu sekolah dasar. Jakarta : Bumi Aksara.

Danim, S. (2008). Visi Baru Manajemen Sekolah. Jakarta: PT Bumi Aksara.

Danim, S. (2009). Manajemen dan Kepemimpinan Transformasional Kekepalasekolahan. Jakarta: Rineka Cipta.

Engkoswara. (2012). Administrasi Pendidikan. Bandung: Alfabeta.

Fatah, N. (2013). Sistem Penjaminan Mutu Pendidikan. Bandung: PT Remaja Rosdakarya.

Fathurrohman, P. (2011). Supervisi Pendidikan dalam Pengembangan Proses Pengajaran. Bandung: PT Refika Aditama.

Hendarman. (2018). Kepala sekolah sebagai Manajer. Bandung: PT Remaja Rosdakarya.

Hidayat, I. M. (2018). The Hand Book of Education Management. Jakarta: Kencana Prenadamedia Group. 
Holidi, D. (2012). Pedoman Manajemen Supervisi Kepala Sekolah dan Pengawas. Tangerang: PT Griya Widya Pustaka.

Moleong, L. J. (2017). Metodologi Penelitian Kualitatif. Jakarta: PT Remaja Rosdakarya.

Mulyasa, E. (2009). Manajemen Berbasis Sekolah Konsep Strategi dan Implementasi. Bandung: PT Remaja Rosdakarya.

Mustofa, J. A. (2013). Supervisi Pendidikan Terobosan Baru dalam Peningkatan Kinerja Pengawas Sekolah dan Guru. Yogyakarta: Ar-Ruzzmedia.

Nata, A. (2012). Kapita Selekta Pendidikan Islam. Jakarta: PR RajaGrafindo Persada.

Nata, A. (2012). Manajemen Pendidikan Mengatasi Kelemahan Pendidikan Islam di Indonesia. Jakarta: Kencana Predana Media Group.

Nurhayati, A. H. (2014). Manajemen Mutu Pendidikan. Bandung: Alfabeta.

Pidarta, M. (2004). Manajemen Pendidikan Indonesia. Jakarta: PT Rineka Cipta.

Purwanto, M. N. (2009). Administrasi dan Supervisi Pendidikan. Bandung: PT Remaja Rosdakarya.

Rawita, I. S. (2010). Kebijakan Pendidikan. Yogyakarta: Kurnia Kalam Semesta.

Rawita, I. S. (2013). Mengelola Sekolah Efektif Perspektif Manajerial dan Iklim Sekolah. Jakarta: LaskBang.

Riduwan. (2012). Belajar Mudah Penelitian untuk Guru - karyawan dan Peneliti Pemula. Bandung: Alfabeta.

Rivai, V. (2012). Education Management. Jakarta: PT Raja Grafindo Persada.

Rivai, V. (2013). Kepemimpinan dan Perilaku Organisasi. Jakarta: PT RajaGrafindo Persada.

Rohiat. (2012). Manajemen Sekolah. Bndung: PT Refika Aditama.

Rosyada, D. (2013). Paradigma Pendidikan Demokratis sebuah Model Pelibatan Masyarakat dalam Penyelenggaraan Pendidikan. Jakarta: Kencana.

Rosyada, D. (2017). Madrasah dan Profesionalisme Guru salam Arus Dinamika Pendidikan Islam di Era Otonomi Daerah. Depok: Kencana Prenadamedia Group.

Sallis, E. (2010). Total Quality Management in Education Manajemen Mutu Pendidikan. Yogyakarta: IRCiSod.

Sugiono. (2013). Metode Penelitian Pendidikan Pendekatan Kuantitatif, Kualitatif, dan $R$ \& D. Bandung: Alfabeta.

Suhardiman, B. (2012). Studi Pengembangan Kepala sekolah . Jakarta: Rineka Cipta.

Sukmadinata, N. S. (2010). Metode Penelitian Pendidikan. Bandung: PT Remaja Rosdakarya.

Supardi. (2013). Sekolah Efektif Konsep Dasar dan Praktiknya. Jakarta: PT Raja Grafindo Persada.

Tilaar, H. (2012). Standarisasi Pendidikan Nasional suatu Tinjauan Kritis. Jakarta: PT Rineka Cipta. 
Triatna, A. K. (2010). Visionary Leadership Menuju Sekolah Efektif. Jakarta: Bumi Aksara.

Umiarso. (2010). Manajemen Mutu Sekolah di Era Otonomi Pendidikan . Yogyakarta: IRCiSoD.

Usman, H. (2013). Manajemen Teori, Praktik, dan Riset Pendidikan. Jakarta : Bumi Aksara.

Wukir. (2013). Manajemen Sumber Daya Manusia dalam Organisasi Sekolah. Yogyakarta: Multi Presindo.

Yamin, M. (2012). Panduan Manajemen Mutu Kurikulum Pendidikan. Yogyakarta: DIVA Press.

Yukl, G. (2010). Kepemimpinan dalam Organisasi. Jakarta: PT Indeks. 